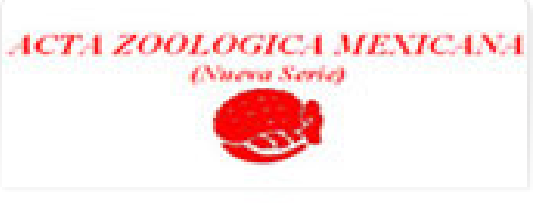

\section{Acta Zoológica Mexicana (nueva serie)}

ISSN: 0065-1737

azm@ecologia.edu.mx

Instituto de Ecología, A.C.

México

Romero Nàpoles, Jesús; Yus Ramos, Rafael

A new species of acanthoscelides schilsky, 1905 (coleoptera: bruchidae) from Oaxaca, México, with

new distribution records of bruchidae for this state

Acta Zoológica Mexicana (nueva serie), vol. 24, núm. 2, 2008, pp. 95-100

Instituto de Ecología, A.C.

Xalapa, México

Disponible en: http://www.redalyc.org/articulo.oa?id=57524206

- Cómo citar el artículo

- Número completo

- Más información del artículo

Página de la revista en redalyc.org

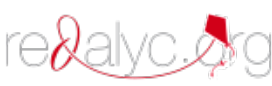

Sistema de Información Científica

Red de Revistas Científicas de América Latina, el Caribe, España y Portugal

Proyecto académico sin fines de lucro, desarrollado bajo la iniciativa de acceso abierto 


\title{
A NEW SPECIES OF ACANTHOSCELIDES SCHILSKY, 1905 (COLEOPTERA: BRUCHIDAE) FROM OAXACA, MEXICO, WITH NEW DISTRIBUTION RECORDS OF BRUCHIDAE FOR THIS STATE
}

\author{
Jesús ROMERO-NÁPOLES ${ }^{1}$ and Rafael YuS-RAMOS ${ }^{2}$ \\ 1Instituto de Fitosanidad, Colegio de Postgraduados, Texcoco, ESTADO DE MÉXICO; \\ Email: jnapoles@colpos.mx \\ 2Urb.E1 Jardín nº 22, Vélez-Málaga. 29700 (Málaga, SPAIN) \\ Email: rafayus@telefonica.net
}

RESUMEN

\begin{abstract}
Se describe e ilustra una nueva especie de Acanthoscelides colectado en Oaxaca, México; además se proporcionan nuevos registros de distribución de Bruchidae para el estado.

Palabras Clave: Bruchidae, Acanthoscelides, taxonomía, bruquidos neotropicales, escarabajos de las
\end{abstract} semillas.

\section{ABSTRACT}

A new species of Acanthoscelides collected in Oaxaca, Mexico, is described and figured and new distribution records of Bruchidae for the State are given.

Key words: Bruchidae, Acanthoscelides, taxonomy, neotropical bruchids, seed beetles.

\section{INTRODUCTION}

Johnson et al. (2004) estimated that there are about 1,700 named species worldwide. For Mexico, the most recent work about bruchid diversity (Romero \& Johnson 2004), states that there are 334 species in 23 genera, or $19.67 \%$ of the total species.

According to Johnson (1990) the genus Acanthoscelides is the largest in the New World Bruchidae, containing about 340 species, however, there are more than 200 species remaining to be described. A checklist published in 2004 states that for Mexico there are 119 species of Acanthoscelides, 35\% of the species recorded for this endemic genus of the New World (Romero \& Johnson 2004); however, for the State of Oaxaca there are only 55 species. 


\section{MATERIAL AND METHODS}

For the study of the species we used the methods described by Kingsolver (1970) and Kingsolver and Whitehead (1974). For interpretation of genitalia we follow Romero and Johnson (1999). We used the terminology and taxonomic characters used by Johnson $(1983,1990)$.

\section{RESULTS}

Acanthoscelides alonsoi Romero and Yus, new species

\section{Description}

\section{Male}

Measurements: Length (pronotum-elytra) 1.38 to $1.8 \mathrm{~mm}$. Width 0.95 to $1.13 \mathrm{~mm}$. Maximum thoracic depth 0.6 to $0.88 \mathrm{~mm}$.

Integumental color: Head reddish brown with frons and clypeus dark brown; antennal segments reddish to dark brown; pronotum, elytron and pygidium variegate, spots may vary from reddish to dark brown; legs reddish, metacoxa dark brown, metatrochanter reddish to dark brown; rest of the body brown to dark brown.

Vestiture: With recumbent white, golden, brown, and black hairs as follows; postocular lobe with short white setae; postocular patch of dense white or golden hairs; remainder of head with moderately dense white or intermixed white or golden hairs; pronotum variegated with irregular maculations of white, golden and dark hairs, median basal lobe with dense white pubescence (Fig. 1d); elytral vestiture varied with maculations of golden, white, brown and black hairs in a distinct pattern; intervals between striae 1 and 2,3 and 4,5 and 6,7 and 8,9 and 10 with usually uniform white or golden or intermixed white and golden hairs; intervals between stria 2 and 3,4 and 5,6 and 7, 8 and 9 with large elongate patches of dense white hairs interrupted by shorter patches of dark or black hairs (Fig. 1a); base of metepisternum, apex of metacoxa and lateral areas of ventral segments 2 to 5 with dense white hairs; legs with sparse white hairs; undersurfaces with moderately dense white to golden pubescence; pygidial pubescence varying from uniform, moderately dense white hairs to white or brown hairs with a dense median stripe of white hairs.

Structure: Head. Short and broad, densely micropunctulate; frons with median carina; distance between eyes 0.60 to 0.66 as wide as eye width; eye cleft to 0.58 to 0.73 its length by ocular sinus; posterior margin of eye protruding from adjacent surfaces; postocular lobe rounded; distance from base of antennae to apex of labrum 0.58 to 0.44 as long as distance from upper limits of eyes to apex of labrum (Fig. 1a); antennal segment one submoniliform, 2, 3 moniliform to filiform, 4 subserrate, 5 to 10 serrate, 11th subacute apically; antenna 
extending to humerus or slightly beyond (Figs. 1a,b). Prothorax.- Disk campanulate, foveolate; cervical sulcus moderately deep, extending from near coxal cavity to about 0.56 to 0.63 distance to pronotal midline (Fig. 1d); lateral prothoracic carina extending from base to 0.44 to 0.50 distance to coxal cavity; without short median impressed line on median basal lobe; prosternum separating procoxae for 0.70 to 0.83 their length. Mesothorax and Metathorax.- Scutellum black, quadrate, clothed with dense white hairs; elytron about twice as long as broad; striae deep, punctate, strial intervals punctulate; distance between striae at base subequal; striae 2, 3 and 4 with small denticles at their bases; humerus punctulate, glabrous, shiny black (Fig. 1a); undersurfaces and all of hind coxa punctulate, metepisternum coarsely foveolate. Legs.- First and second front tarsomeres similar; first medium tarsomere 3 times as long as second (Figs. 1e-f); hind femur constricted basally and apically, expanded medially to slightly more than width of coxa; femur armed with subapical acuminate spine about 1.3 to 1.4 time as long as width of tibial base and 3 acuminate spines about 0.4 to 0.5 as long as first spine; hind tibia with ventral, lateroventral, lateral and dorsomesal glabrous longitudinal carinae; with lateroventral and lateral carina; dorsal surface of tibia without fossa; tibial corona with 4 spinules, mucro 0.11 to 0.18 as long as first tarsomere; without sinus at base of spine; first hind tarsomere with ventral and lateral glabrous longitudinal carina, it is 1.5 to 1.6 times longer than first tarsomere of mesoleg (Figs. 1e-g). Abdomen. First sternum with median oval depression, clothed with dense white hairs, posterior margin straight, longer than remaining sterna; sterna 2 to 4 similar in size; fifth emarginate; pygidium foveolate, convex in lateral view (Fig. 1j).

Genitalia: Median lobe moderate in length; in ventral view, ventral valve truncate at apex, lateral margins slightly concave; armature of internal sac with apical spiniscent mass mixed with dentate scales, and a basal spiniscent mass in which spinules are bigger than the first one (Fig. 2a). Lateral lobes elongate slightly expanded at apex, cleft to about 0.11 their length (Fig. 2b).

\section{Female}

Measurements: Length (pronotum-elytra) 1.63 to $1.88 \mathrm{~mm}$. Width 1.13 to $1.25 \mathrm{~mm}$. Maximum thoracic depth 0.8 to $0.95 \mathrm{~mm}$.

Similar to male except antennae slightly shorter (Fig. 1c), first sternum without median oval depression and fifth abdominal sternum not emarginate at apex (Fig. 1i).

Host Plant. Senna sp.: San Felipe del Agua, Oaxaca, 28/IV/2004, M. A. Alonso collector.

Type series. Holotype male, allotype female and paratypes: San Felipe del Agua, Oaxaca, 28/IV/2004, M. A. Alonso collector. Holotype deposited at Museo Nacional de Ciencias Naturales (MNCN), allotype at Florida State Collection of Arthropods (FSCA), paratypes at FSCA $\left(1 \sigma^{\nearrow}\right)$ Coleccion Entomologica del Instituto de Fitosanidad (CEAM, $2 \sigma^{7}-1$ \%), MNCN

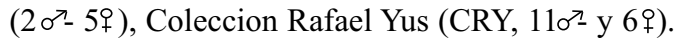

Distribution. Mexico (Oaxaca). 

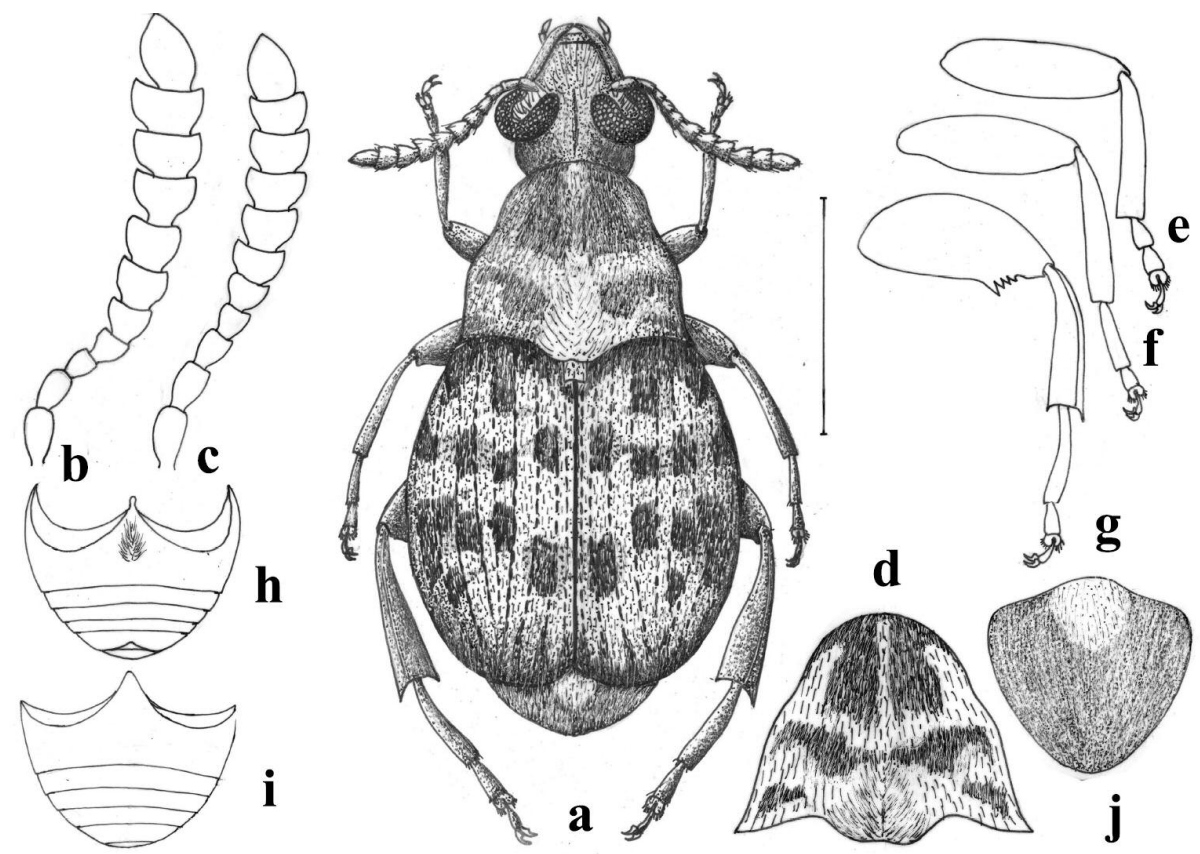

Fig. 1. Acanthoscelides alonsoi; a) dorsal view, b) male antenna, c) female antenna d) pronotum, e) prothoracic leg, f) mesothoracic leg, g) metathoracic leg, h) male abdomen, i) female abdomen, j) pygidium.

Etymology. The specific epithet refers to the first surname of Dr. Miguel Angel Alonso Zarazaga, entomologist of the National Museum of Natural Sciences (Madrid, Spain), who collected all the type series.

Diagnosis. Acanthoscelides alonsoi belongs to mexicanus group, because it shares a mucro of about one-sixth as long as the first tarsomere, femora broader than the hind coxa, subapical hind femora spines that equal to or 2 times as long as the width of the tibial base, variegated elytra, and a raised globose area on the vertex; however, the characters elytral striae 3 and 4 abbreviated at their bases and eyes equal to or 12 times the width of the frons do not fit in this new species. According to Johnson $(1983,1989,1990)$ there are 19 species in mexicanus group. All of the known host plants in this group are mimosoid legumes except $A$. jolyi, $A$. obrienorum and $A$. sennicola, and now the new species $A$. alonsoi which feed in seeds of Senna (Caesalpinioideae). The same author states that most species in the group have male genitalia whose ventral valve is truncate at its apex with concave sides and two large or elongate spiniscent masses in the internal sac without sclerites. The new species $A$. alonsoi has in the internal sac two masses of different kind of spinules that are very distinctive for this new species. 

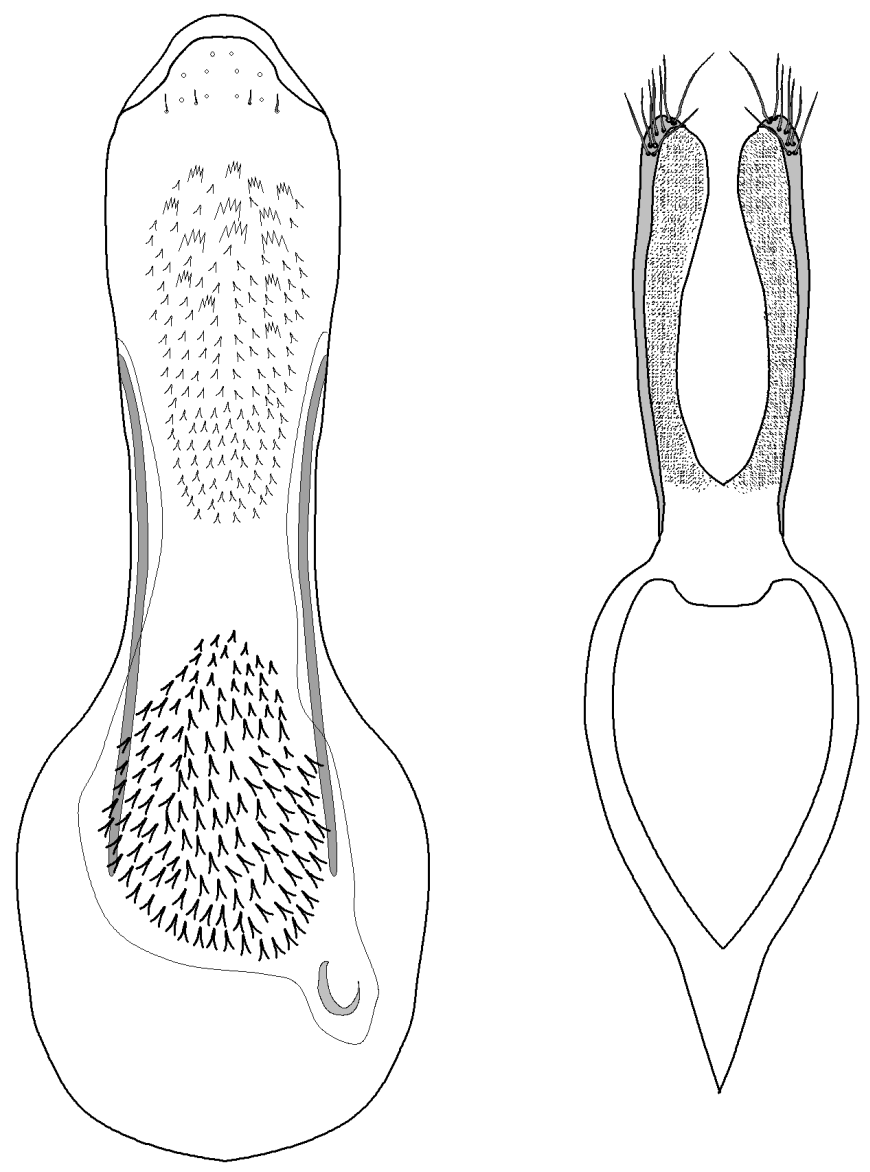

Fig. 2. Acanthoscelides alonsoi male genitalia; a) median lobe, b) lateral lobes.

New records of Bruchidae to Oaxaca

Acanthoscelides luteus Johnson: km 28 carr. Nochixtlan-Huajuapan, Sta. María Tutla, San Andres Dinicuiti, Oaxaca; 9/X/2003; 1955 m; Romero N. J. col.; 17²4'55'”N, 97³8'27' W. Amblycerus alternatus (Pic): Zicatela, Oaxaca; 4/V/2004; Sánchez G.J.A. col. Megacerus alabani Teran \& Kingsolver: km 2 carr. San Juan Guichicovi-Zacatal, Oaxaca; 19/III/1990; 420 m; Barrera E. \& A. Cadena col. Megacerus contaminatus (Sharp): Cañon de León, km 14 carr Oaxaca-Tuxtepec Hwy 175, Oaxaca; 6/X/2003; 1979 m; Romero N.J. col.; $17^{\circ} 08^{\prime} 22^{\prime}$ N, 96³7'43'W. Sennius auricomus Johnson \& Kingsolver: km 28 carr. Nochixtlan-Huajuapan, Sta. María Tutla, San Andres Dinicuiti, Oaxaca; 9/X/2003; 1955 m; 
Nápoles \& Ramos: A new species of Acanthoscelides (Coleoptera: Bruchidae)

Romero N. J. col.; 1741'55'N, 97³8'27'W. Sennius inanis (Sharp): El Tomatal, Oaxaca; 6/V/2004; Sánchez G.J.A. col. Zabrotes densus (Horn): 2 km W El Tomatal, Santa María Colotepec, Oaxaca; 3/VII/2003; Sánchez G.J.A. col.

\section{LITERATURE CITED}

Johnson, C.D. 1983. Ecosystematics of Acanthoscelides (Coleoptera: Bruchidae) of Southern Mexico and Central America. Misc. Publ. Entomol. Soc. Amer. 56.

- 1989. Adaptive Radiation of Acanthoscelides in Seeds: Examples of Legume-Bruchid Interactions. In: C.H. Stirton and J.L. Zarucchi (Eds.). Advances in Legume Biology. Monogr. Syst. Bot. Missouri Bot. Gard. 29:747-779.

Johnson, C.D. 1990. Systematics of the seed beetle genus Acanthoscelides (Bruchidae) of Northern South America. Transactions of the American Entomological Society 116(2): 297-618.

Johnson, C. D., B. J. Southgate \& A. Delobel. 2004. A Revision of the Caryedontini (Coleoptera: Bruchidae: Pachymerinae) of Africa and the Middle East. Memoirs of the American Entomological Society Number 44. 120 p.

Kingsolver, J.M. 1970. A study of male genitalia in Bruchidae (Coleoptera). Proc. Entomol. Soc. Wash. 72:370-386.

Kingsolver, J.M. \& D.R. Whitehead. 1974. Classification and comparative biology of the seed beetle genus Caryedes Hummel (Coleoptera: Bruchidae). Transactions of the American Entomological Society 100: 341-436.

Romero N., J. \& C.D. Johnson. 2004. Checklist of the Bruchidae (Coleoptera) of Mexico. The Coleopterists Bulletin 58(4):613-635.

Recibido: 12 de diciembre de 2007

Aceptado: 7 de marzo de 2008 